\title{
The Effect of Selected Parameters on Spelt Dehulling in a Wire Mesh Cylinder
}

\author{
Andrzej Anders, Ewelina Kolankowska ${ }^{\circledR}$, Dariusz Jan Choszcz ${ }^{\circledR}$, Stanisław Konopka ${ }^{\circledR}$ \\ and Zdzisław Kaliniewicz *(D)
}

Department of Heavy Duty Machines and Research Methodology, University of Warmia and Mazury in Olsztyn, 10-719 Olsztyn, Poland; andrzej.anders@uwm.edu.pl (A.A.); ewelina.kolankowska@uwm.edu.pl (E.K.); dariusz.choszcz@uwm.edu.pl (D.J.C.); stanislaw.konopka@uwm.edu.pl (S.K.)

* Correspondence: zdzislaw.kaliniewicz@uwm.edu.pl; Tel.: +48-089-523-39-34

Received: 29 October 2019; Accepted: 14 December 2019; Published: 19 December 2019

check for updates

\begin{abstract}
A spelt dehuller with an innovative structural design is described in the study. In the developed solution, spelt kernels are separated by the mechanical impact of friction in a wire mesh cylinder with $4 \times 4 \mathrm{~mm}$ openings. The dehuller is powered by a motor with a rotating impeller with an adjustable blade angle. In the experimental part of the study, spelt kernels are dehulled at five rotational speeds of the shaft: 160 to $400 \mathrm{rpm}$ at intervals of $60 \mathrm{rpm}$, and five rotor blade angles: $50^{\circ}$ to $90^{\circ}$ at intervals of $10^{\circ}$. The efficiency of spelt dehulling (removal of glumes and glumelles) is evaluated based on kernel separation efficiency, husk separation efficiency, and the proportion of damaged kernels.
\end{abstract}

Keywords: spelt; threshing; dehuller

\section{Introduction}

Sustainable agriculture is the production of healthy, high-quality foods in a way that protects the environment and provides economic benefits to farmers. Spelt as well as emmer and einkorn are ancient wheat species. Spelt is a relict species that has recently been "rediscovered" and is being widely used in the production of flour, groats, flakes, pasta, bread, vodka, and beer [1,2]. The growing popularity of spelt on the consumer market can be attributed to its unique flavor, health-promoting properties, environmental benefits, and high content of biologically active compounds including essential nutrients. Spelt grain contains high-quality protein; unsaturated fatty acids; B complex vitamins; PP vitamin (niacin, vitamin B3, and pellagra-preventing factor); and minerals such as zinc, potassium, calcium, and iron [3-6]. Spelt kernels are enveloped by tough husks that protect this grain against atmospheric pollution and radiation. Tough husks are difficult to separate, which poses a considerable problem during threshing and limits the processing suitability of spelt grain. Spelt is difficult to harvest because grain is not effectively separated from spikelets by combine harvesters. Spelt spikes are hard, awned or awnless, and nonfree-threshing. Loose spikes have a brittle rachis, which is broken during threshing into several fragments, and each fragment contains one spikelet. Spikelets typically have two flowers with two kernels per spikelet, and kernels are tightly enclosed by four glumelles and two glumes, which makes the species nonfree-threshing. Spelt spikelets rarely contain three kernels. Spelt kernels are vitreous, white to red in color, with distinctive brush hairs in the apical part $[7,8]$.

The harvested grain cannot be directly used in the food processing industry due to considerable contamination with chaff. After harvest, spikelets require additional treatment in a process that is commonly referred to as threshing. The harvested material is a mixture of grain and spikelets. This mixture has to be separated before threshing, because repeated threshing only increases energy consumption, contributes to grain damage, and increases grain loss [9]. 
The popularity of spelt is on the rise in the agricultural sector, in particular in organic farms. According to Mieczysław Babalski, one of the leading spelt producers in Poland, and Józef Tyburski, $\mathrm{PhD}$, spelt can be effectively dehulled in a modified thresher, an abrasive discdehuller, or specialist equipment manufactured in Western Europe $[7,8,10]$. Shelling machines and tangential dehullers can also be used for this purpose [11]. Most commercially available dehulling machines feature a cylindrical sieve and a rotating impeller with beaters. However, their efficiency is not highly satisfactory because spelt grain is encased by tightly adhering husks. Dehulling machines are also very expensive, and many farmers make attempts to build their own dehulling equipment. For instance, Tudor (2012) designed and built a dehulling machine as part of the Farmer FNE11-731 project [12]. It should also be noted that the grain and spikelet mixture has to be cleaned several times during supplementary threshing.

Dehulling devices are not highly efficient in separating spelt grain from husks, and they are very expensive. In Polish farms, modified clover hullers are often used for the supplementary threshing of spelt. However, spelt grain is not effectively separated by modified clover hullers, and the processed material requires further cleaning and sorting.

To address these concerns, a spelt dehuller with an innovative structural design is proposed in this study [13]. In the developed solution, spelt kernels are separated by the mechanical impact of friction in a wire mesh cylinder with $4 \times 4 \mathrm{~mm}$ openings. The dehuller is powered by a motor with a rotating impeller, and the blade angle can be adjusted from $50^{\circ}$ to $90^{\circ}$, at intervals of $10^{\circ}$ [14]. The aim of the study is to determine the effect of selected parameters (rotor blade angle and rotational speed of the shaft) on the efficiency of glume and glumelle removal from spelt kernels.

\section{Materials and Methods}

The experimental material comprised spikelets of spelt cv. Schwabenkorn purchased in an organic farm in Praslity (54 $01^{\prime} 55^{\prime \prime}$ N 20 $21^{\prime} 29^{\prime \prime}$ E), municipality of Dobre Miasto, Region of Warmia and Mazury in Poland. The experimental material (spelt) was purchased from an organic farm (not from a commercial seed center) immediately after harvest. In order to remove impurities, weeds, and kernels of other cereal species, the seeds were cleaned using screens/sieves and a pneumatic separator. The percentage share of seeds of the main species in an average sample of input material (purity of the examined material) was determined at $85 \%$, and its relative moisture content was determined at $11.56 \pm 2.00 \%$.

The proposed dehuller (Figure 1) features a wire mesh cylinder with $4 \times 4 \mathrm{~mm}$ openings (Figure 2) and an open area factor (as a ratio (percentage) of the area available for the material to pass (openings) to the total area of the screen) of 0.38 . Cylindrical mesh sieves are generally applied in specialist machines for separating spelt grain from chaff and in modified clover hullers.

The experiment was conducted in two stages. The process of removing husks from spelt kernels was examined in the first stage, and the separation of grain from threshed spikelets was analyzed in the second stage.

The following parameters were adopted in the first stage of the experiment:

1. Fixed parameters:

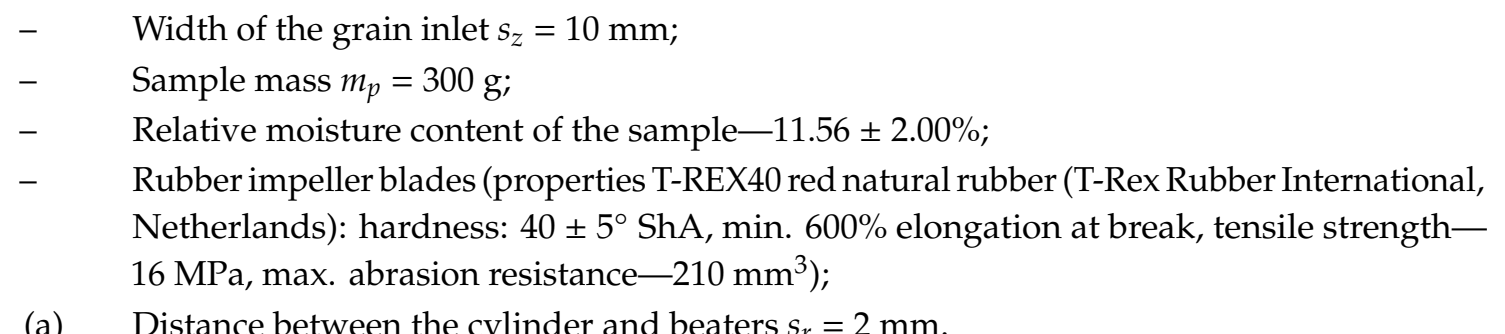

2. Independent variables:

- $\quad$ Rotor blade angle $\alpha \mathrm{w}-50^{\circ} \div 90^{\circ}$, at intervals of $10^{\circ}$;

- $\quad$ Rotational speed of the shaft nw-160 $\div 400 \mathrm{rpm}$, at intervals of $60 \mathrm{rpm}$; 
3. Dependent variables:

- $\quad$ Kernel separation efficiency $\eta_{z}, \%$;

- $\quad$ Husk separation efficiency $\eta_{p}, \%$;

- $\quad$ Proportion of damaged kernels $U_{z}, \%$.

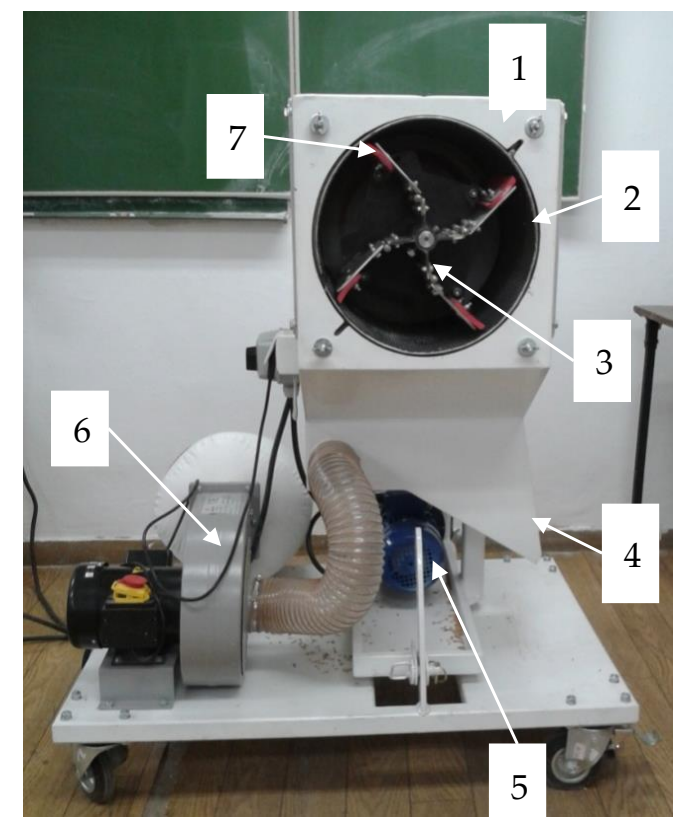

Figure 1. Prototype of a spelt dehuller: 1-dehulling chamber, 2-wire mesh cylinder, 3-rotating impeller, 4-receiving outlet, 5-gearmotor, 6-radial fan, and 7-impeller blades.

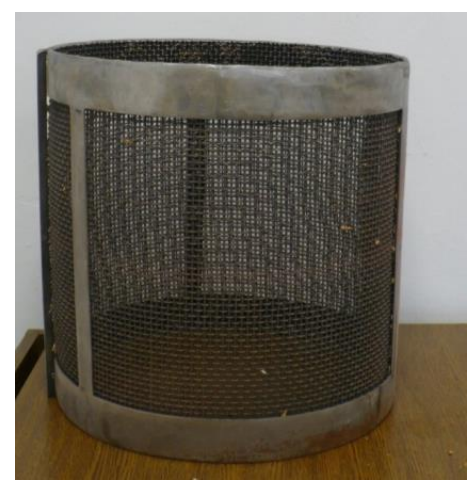

(a)
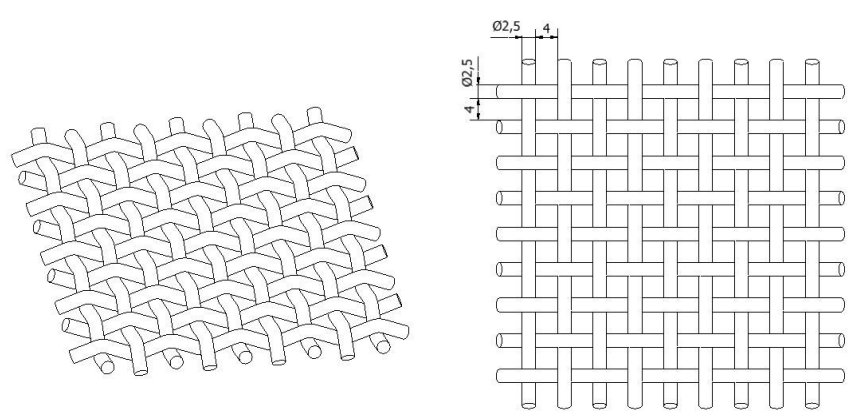

(b)

Figure 2. Wire mesh cylinder with $4 \times 4 \mathrm{~mm}$ openings [15]: (a) cylinder view, (b) sieve structure. 
Kernel and husk separation efficiency $\eta$ and the proportion of damaged kernels $U_{z}$ were determined based on the mass of the mixture components separated in each sample in the first stage of the experiment [16].

In each sample, kernel separation efficiency $\eta_{z}$ was calculated with the use of the following formula:

$$
\eta_{z}=\frac{M_{z}}{M_{c}} \cdot 100 \%
$$

where

$M_{z}$-mass of separated kernels (g),

$M_{c}$-mass share of kernels in a sample (g).

In each sample, husk separation efficiency $\eta_{p}$ was calculated with the use of the following formula:

$$
\eta_{p}=\frac{M_{p}}{M_{m}} \cdot 100 \%
$$

where

$M_{p}$-husk mass (g),

$M_{c}$-mass share of husks in a sample $(\mathrm{g})$.

The proportion of damaged kernels $U_{z}$ was calculated with the use of the following formula:

$$
U_{z}=\frac{M_{u}}{M_{c}} \cdot 100 \%
$$

where

$M_{u}$-mass of damaged kernels ( $\mathrm{g}$ ).

In the first stage of the experiment, the dehuller's operating parameters were set before every measurement. Spelt spikelets were fed into the hopper, and the dehuller was turned on. Machine start-up time was around $30 \mathrm{~s}$. The sliding gate in the hopper was opened, and husks were removed from spikelets by the mechanical impact of friction. The processed material was weighed on a laboratory scale to the nearest $0.01 \mathrm{~g}$. A preweighed sample of spelt spikelets was always present in the feeder hopper to ensure the repeatability of measurements.

In the second stage of the experiment, the threshed material was separated into whole kernels, damaged kernels, spikelets, and husks in a pneumatic separator ([17], Figure 3) and a Fritsch Analysette 3 (Fritsch GmbH, Germany) vibratory sieve shaker. Based on initial measurements, the air flow rate in the pneumatic separator was set at $7.5 \mathrm{~m} \cdot \mathrm{s}^{-1}$. The vibratory sieve shaker consisted of 5 mesh screens with longitudinal openings $(4.0 \times 20 \mathrm{~mm}, 3.5 \times 20 \mathrm{~mm}, 3.0 \times 20 \mathrm{~mm} ; 2.5 \times 20 \mathrm{~mm}$, and $2.0 \times 20 \mathrm{~mm})$. Processing time was $3 \mathrm{~min}$, and the amplitude of vibration was $0.1 \mathrm{~mm}$. Spelt kernels were considered damaged when they were broken, cracked, had a interior visible, or had damaged seed coats. 


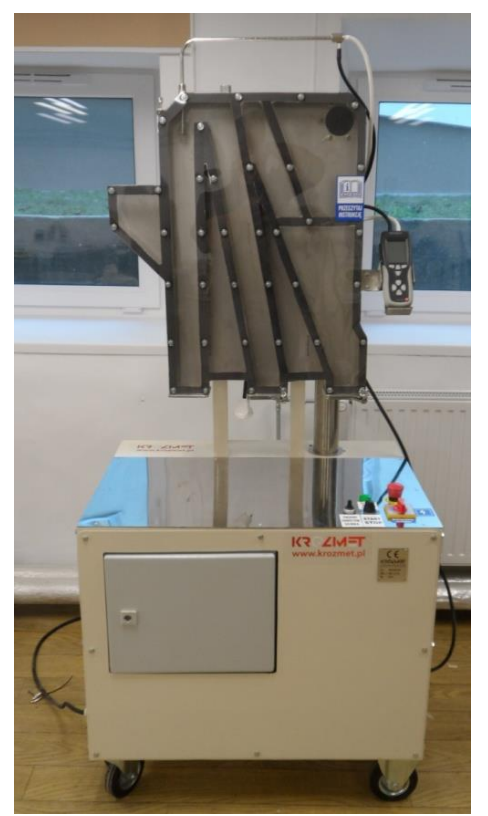

Figure 3. W.124984 pneumatic separator [15].

In all sub-stages of the experiment, the measurements for each combination of independent variables were performed in triplicate.

The results of all measurements were processed statistically by correlation analysis and stepwise multivariate polynomial regression analysis for a second-order polynomial model. Statistical analyses were conducted in Statistica PL v. 13.1 [18].

\section{Results and Discussion}

The results of the statistical analysis of the proportion of spelt kernels damaged at different rotor blade angles and rotational speeds are presented in Table 1.

The results of the multiple regression analysis indicate that the correlation coefficient for the proportion of spelt kernels damaged during threshing in a wire mesh cylinder with $4 \times 4 \mathrm{~mm}$ openings at the tested rotor blade angles and rotational speeds ranged from 0.32 to 0.58 . The multiple regression equations describing the proportion of damaged kernels generally fit the empirical data well, and the coefficient of determination for the wire mesh cylinder reached 0.70 .

The equations describing the percentage of kernels damaged at different rotor blade angles and rotational speeds are presented graphically in Figure 4 . In the wire mesh cylinder with $4 \times 4 \mathrm{~mm}$ openings, the proportion of damaged kernels increased with a rise in rotational speed in the following range of rotor blade angles: $\alpha_{w}=70^{\circ} \div 80^{\circ}$.

In the tested wire mesh cylinder, the efficiency of kernel separation was highly correlated with rotational speed, and the value of the correlation coefficient was determined at 0.84 (Table 2). The efficiency of kernel separation was less correlated with the rotor blade angle, and the value of the correlation coefficient was determined at 0.23 . The multiple regression equation describing the efficiency of kernel separation was characterized by good and very good fit to empirical data. In the wire mesh cylinder with $4 \times 4 \mathrm{~mm}$ openings, the coefficient of determination after stepwise elimination of non-significant variables was determined at 0.88 .

The quadratic equation describing kernel separation efficiency at different rotor blade angles and rotational speeds is presented graphically in Figure 5. In the wire mesh cylinder with $4 \times 4 \mathrm{~mm}$ openings, kernel separation efficiency increased with a rise in rotational speed. The rotor blade angle exerted a smaller and more ambiguous effect on kernel separation efficiency. Kernels were most efficiently separated at a rotational speed of $400 \mathrm{rpm}$ and a rotor blade angle of $90^{\circ}$. 
Table 1. A correlation analysis of the proportion of spelt kernels damaged during threshing in a wire mesh cylinder with $4 \times 4 \mathrm{~mm}$ openings.

\begin{tabular}{|c|c|c|c|c|}
\hline \multicolumn{5}{|c|}{$\begin{array}{l}\text { General Data: } \\
\text { Correlation Coefficients are Significant at } \alpha<0.05 \\
N=25\end{array}$} \\
\hline No. & Variable & Mean & $\begin{array}{l}\text { Standard } \\
\text { Deviation }\end{array}$ & $\begin{array}{l}\text { Coefficient of } \\
\text { Variation (\%) }\end{array}$ \\
\hline 1. & Rotor blade angle $\alpha_{w}\left(^{\circ}\right)$ & 70.00 & 14.43 & 20.62 \\
\hline 2. & Rotational speed $n_{w}(\mathrm{rpm})$ & 280.00 & 86.60 & 30.93 \\
\hline 3. & Proportion of damaged kernels $U_{z}(\%)$ & 4.74 & 3.96 & 83.60 \\
\hline \multicolumn{5}{|c|}{ Correlation Matrix } \\
\hline & & $\alpha_{w}$ & $n_{w}$ & $U_{z}$ \\
\hline & $\alpha_{w}$ & 1 & 0 & 0.584 \\
\hline & $n_{w}$ & & 1 & 0.320 \\
\hline & $U_{z}$ & & & 1 \\
\hline Variable & F-Statistic & $\begin{array}{c}\text { Coefficient of } \\
\text { Determination } R^{2}\end{array}$ & $\begin{array}{l}\text { Standard } \\
\text { Error of the } \\
\text { Estimate }\end{array}$ & $t$-Statistic \\
\hline Free term & \multirow{6}{*}{8.81} & \multirow{6}{*}{0.70} & \multirow{6}{*}{2.44} & -3.18 \\
\hline$\alpha_{w}$ & & & & 3.76 \\
\hline$\alpha_{w}^{2}$ & & & & -3.84 \\
\hline$n_{w}$ & & & & -0.30 \\
\hline$n_{w}^{2}$ & & & & -0.04 \\
\hline$\alpha_{w} \cdot n_{w}$ & & & & 1.14 \\
\hline
\end{tabular}

Quadratic equation for two independent variables:

$U_{z}=1.601419 \cdot \alpha_{w}-0.011224 \cdot \alpha_{w}^{2}-0.016039 \cdot n_{w}-0.000003 \cdot n_{w}^{2}+0.000465 \cdot \alpha_{w} \cdot n_{w}-54.454576$

Stepwise regression did not decrease the degree of the polynomial function for two independent variables

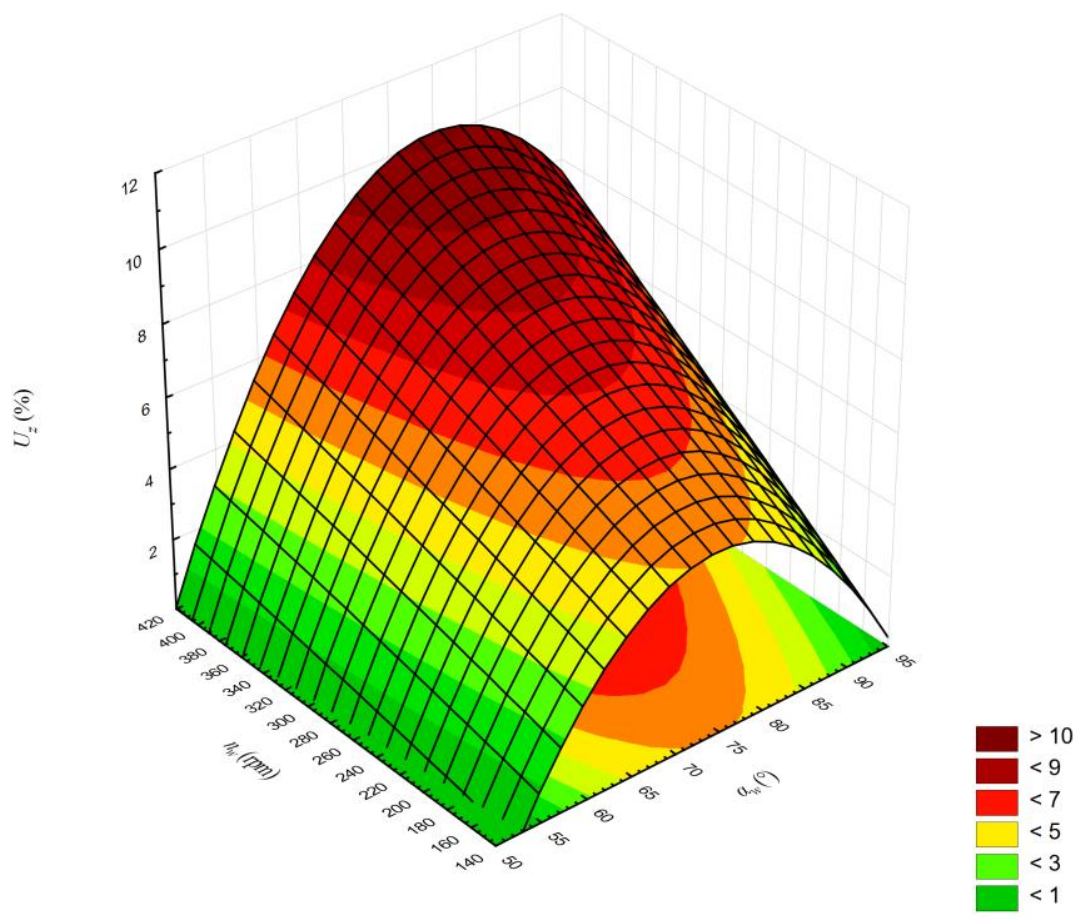

Figure 4. Proportion of kernels damaged at different rotor blade angles $\alpha_{w}$ and rotational speeds $n_{w}$ in a wire mesh cylinder with $4 \times 4$ mm openings. 
Table 2. A correlation analysis of kernel separation efficiency during threshing in a wire mesh cylinder with $4 \times 4 \mathrm{~mm}$ openings.

\begin{tabular}{|c|c|c|c|c|}
\hline \multicolumn{5}{|c|}{$\begin{array}{l}\text { General Data: } \\
\text { Correlation Coefficients are Significant at } \alpha<0.05 \\
\quad N=25\end{array}$} \\
\hline No. & Variable & Mean & $\begin{array}{l}\text { Standard } \\
\text { Deviation }\end{array}$ & $\begin{array}{l}\text { Coefficient of } \\
\text { Variation }(\%)\end{array}$ \\
\hline 1. & Rotor blade angle $\alpha_{w}\left({ }^{\circ}\right)$ & 70.00 & 14.43 & 20.62 \\
\hline 2. & Rotational speed $n_{w}(\mathrm{rpm})$ & 280.00 & 86.60 & 30.93 \\
\hline 3. & Kernel separation efficiency $\eta_{z}(\%)$ & 52.14 & 8.58 & 16.46 \\
\hline \multicolumn{5}{|c|}{ Correlation Matrix } \\
\hline & & $\alpha_{w}$ & $n_{w}$ & $\eta_{z}$ \\
\hline & $\alpha_{w}$ & 1 & 0 & 0.226 \\
\hline & $n_{w}$ & & 1 & 0.845 \\
\hline & $\eta_{z}$ & & & 1 \\
\hline Variable & F-Statistic & $\begin{array}{c}\text { Coefficient of } \\
\text { Determination } R^{2}\end{array}$ & $\begin{array}{l}\text { Standard } \\
\text { Error of the } \\
\text { Estimate }\end{array}$ & $t$-Statistic \\
\hline Free term & & & & 5.65 \\
\hline$\alpha_{w}$ & 53.77 & 088 & 311 & -4.41 \\
\hline$\alpha_{w}^{2}$ & 53.77 & 0.88 & 3.11 & 4.68 \\
\hline$n_{w}$ & & & & 11.41 \\
\hline \multicolumn{5}{|c|}{$\begin{array}{l}\text { Quadratic equation for two independent variables: } \\
\eta_{z}=-2.3039 \cdot \alpha_{w}+0.0174 \cdot \alpha_{w}^{2}+0.0837 \cdot n_{w}+101.1434\end{array}$} \\
\hline
\end{tabular}

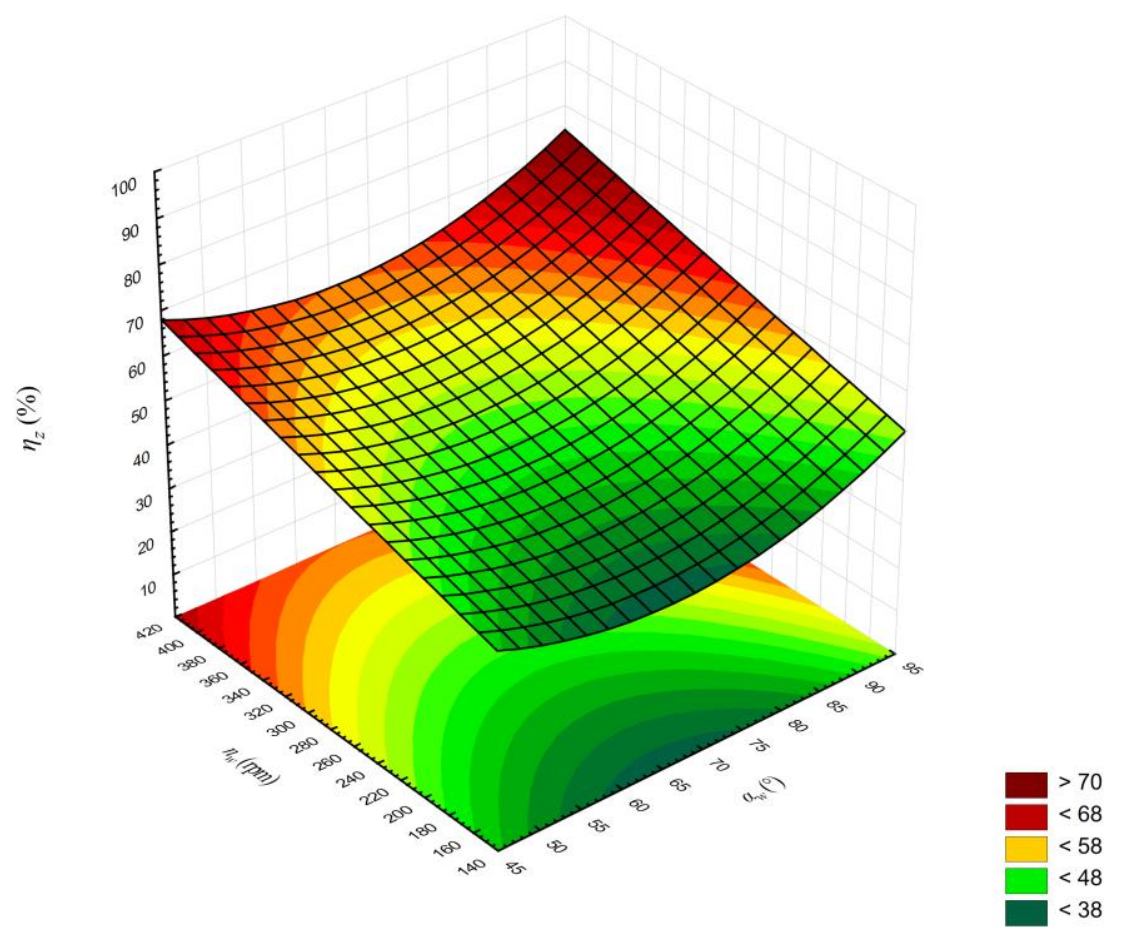

Figure 5. Kernel separation efficiency at different rotor blade angles $\alpha_{w}$ and rotational speeds $n_{w}$ in a wire mesh cylinder with $4 \times 4 \mathrm{~mm}$ openings.

Husk separation efficiency was measured at different rotor blade angles and rotational speeds; the results were processed statistically and are presented in Table 3 . In the wire mesh cylinder with $4 \times 4 \mathrm{~mm}$ openings, the correlation coefficient between husk separation efficiency and rotor blade angle was determined at 0.67 , and the correlation coefficient between husk separation efficiency and rotational speed was determined at 0.54 . The multiple regression equation describing husk separation efficiency was characterized by a very good fit to empirical data. The value of the coefficient of determination for the tested mesh cylinder was 0.89 . 
Table 3. A correlation analysis of husk separation efficiency during threshing in a wire mesh cylinder with $4 \times 4 \mathrm{~mm}$ openings.

\begin{tabular}{ccccc}
\hline \multicolumn{5}{c}{ Correlation Coefficients are Significant at $\alpha<0.05$} \\
$\mathbf{N}=\mathbf{2 5}$
\end{tabular}

The quadratic equation describing husk separation efficiency at different rotor blade angles and rotational speeds is presented graphically in Figure 6 . In the wire mesh cylinder with $4 \times 4 \mathrm{~mm}$ openings, husks were most effectively separated at the rotational speed of $400 \mathrm{rpm}$ and the rotor blade angle of $90^{\circ}$.

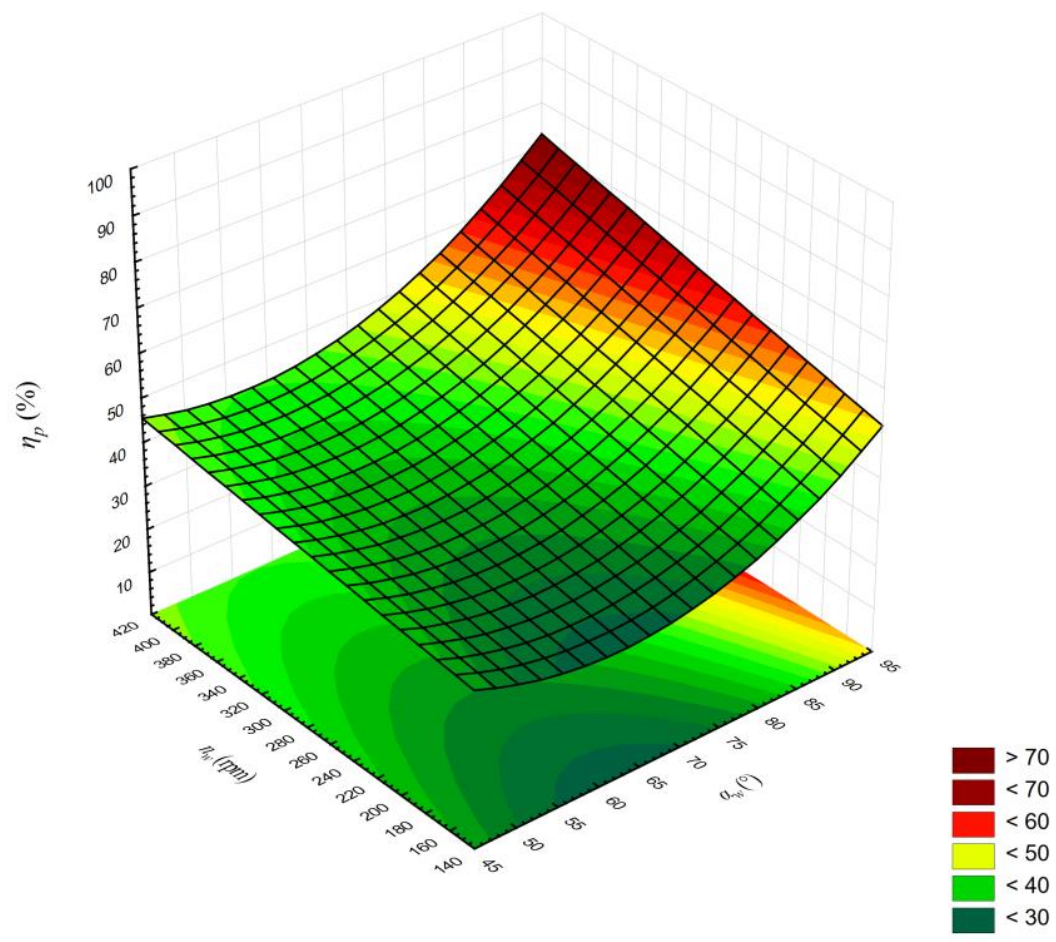

Figure 6. Husk separation efficiency at different rotor blade angles $\alpha_{w}$ and rotational speeds $n_{w}$ in a wire mesh cylinder with $4 \times 4 \mathrm{~mm}$ openings. 


\section{Conclusions}

In the proposed spelt dehuller with an adjustable blade angle, where spelt kernels were separated by the mechanical impact of friction in a wire mesh cylinder with $4 \times 4 \mathrm{~mm}$ openings, the highest proportion of damaged kernels $U_{z}(13.77 \%)$ was noted at a rotational speed of $400 \mathrm{rpm}$ and a rotor blade angle of $80^{\circ}$. Kernel separation efficiency $\eta_{z}$ was highest $(68.72 \%)$ at a rotational speed of 400 $\mathrm{rpm}$ and a rotor blade angle of $50^{\circ}$. Husk separation efficiency $\eta_{p}$ was highest $(60.53 \%)$ at a rotational speed of $400 \mathrm{rpm}$ and a rotor blade angle of $90^{\circ}$.

The proportion of damaged kernels, kernel separation efficiency, and husk separation efficiency in the proposed spelt dehuller can be described by linear equations or stepwise regression for a second-order polynomial model with the elimination of non-significant variables, where the rotor blade angle and rotational speed are the independent variables. The multiple regression equations for the separation process in a wire mesh cylinder with $4 \times 4 \mathrm{~mm}$ openings were characterized by good and very good fit to empirical data. The values of the coefficient of determination $\mathrm{R}^{2}$ ranged from approximately 0.70 to 0.90 .

It can be concluded that the dehulling efficiency of spelt is significantly influenced by both tested variables, i.e., the rotational speed of the impeller $n_{w}$ and the rotor blade angle $\alpha_{w}$.

Grain processing is particularly important in the case of spelt, which has high nutritional value and can be used in the food industry, thus contributing to the development of sustainable agriculture and the extensive use of agricultural resources.

Author Contributions: E.K. and D.J.C. conceived and designed the experiments; E.K. performed the experiments; A.A., D.J.C., S.K., and Z.K. contributed to the literature study; E.K., D.J.C., and S.K. analyzed the data; A.A., E.K., and Z.K. wrote the paper; A.A., D.J.C., and S.K. critically revised the manuscript.

Funding: This research received no external funding.

Conflicts of Interest: The authors declare no conflict of interest.

\section{References}

1. Cegielska, A.; Gromulska, W. Różnorodność produktów z orkiszu (Diverse spelt products). Przegląd Zbożowo-Młynarski 2008, 5, 30-31. (In Polish)

2. Majewska, K.; Dạbkowska, E.; Żuk-Gołaszewska, K.; Tyburski, J. Baking quality of flour obtained from grain of chosen spelt varieties (Triticum spelta L.). Żywność Nauka Technol. Jakość 2007, 2, 60-71.

3. Capouchová, I. Technological quality of spelt (Triticum spelta L.) from ecological growing system. Sci. Agric. Biochem. 2001, 32, 307-322.

4. Kohajdova, Z.; Karovicova, J. Nutritional Value and Baking Applications of Spelt Wheat. Acta Sci. Pol. Technol. Aliment. 2008, 7, 5-14.

5. Wieser, H. Comparative investigations of gluten proteins from different wheat species. III. N-terminal amino acid sequences of a-gliadins potentially toxic for celiac patients. Eur. Food Res. Technol. 2001, 213, 183-186.

6. Abdel-Aal, E.S.M.; Hucl, P. Amino acid composition and in vitro protein digestibility of selected ancient wheats and their end products. J. Food Comp. Anal. 2002, 15, 737-747. [CrossRef]

7. Babalski, M.; Przybylak, Z.; Przybylak, K. Uzdrawiające Ziarna Zbóż (Cereal Grains with Healing Properties); Eko Media: Bydgoszcz, Poland, 2013; pp. 1-191. ISBN 9788363537128. (In Polish)

8. Tyburski, J.; Babalski, M. Uprawa Pszenicy Orkisz (Spelt Cultivation); Centrum Doradztwa Rolniczego w Brwinowie, Oddział w Radomiu: Radom, Poland, 2006; pp. 1-25. ISBN 8360185263. (In Polish)

9. Frączek, J.; Reguła, T. Method of evaluation of susceptibility of spelt grains to mechanical damages during the threshing process. Inżynieria Rol. 2010, 4, 51-58.

10. Choszcz, D.J.; Konopka, S.; Zalewska, K. Characteristics of physical properties of selected varieties of spelt. Inżynieria Rol. 2010, 4, 23-28.

11. Budzyński, W. (Ed.) Pszenice-Zwyczajna, Orkisz, Twarda: Uprawa i Zastosowanie (Common Wheat, Spelt and Durum Wheat: Cultivation and Applications); Powszechne Wydawnictwo Rolnicze i Leśne: Poznań, Poland, 2012; pp. 1-328. ISBN 9788309011354. (In Polish) 
12. Tudor, N. Farmer Built Spelt Dehuller. USDA Sustainable Agriculture Research and Education Report. 2012. Available online: http://mysare.sare.org/MySare/ProjectReport.aspx?do=viewRept\&pn=FNE11--731\&t=1\& $\mathrm{y}=2014$ (accessed on 18 November 2015).

13. Kolankowska, E.; Choszcz, D. Urządzenie do Usuwania Plew z Ziarna Orkiszu (Device for Removing Chaff from Spelt Grain). Patent PL408757, 29 November 2019. (In Polish).

14. Kolankowska, E.; Choszcz, D. Urządzenie do Usuwania Plew z Ziarna Orkiszu (Device for Removing Chaff from Spelt Grain). Utility Model Application No W123522, 31 May 2017. (In Polish).

15. Kolankowska, E. Doskonalenie Procesu Usuwania Plew z Ziarna Orkiszu (Optimization of the Dehulling Process for Spelt Kernels). Ph.D. Thesis, Uniwersytet Warmińsko-Mazurki w Olsztynie, Wydział Nauk Technicznych, Olsztyn, Poland, 2019. (In Polish).

16. Grochowicz, J. Maszyny do Czyszczenia i Sortowania Nasion (Seed Cleaning and Sorting Machines); Wydawnictwo Akademii Rolniczej: Lublin, Poland, 1994; pp. 1-326. ISBN 839016129X. (In Polish)

17. Kolankowska, E.; Choszcz, D. Separator powietrzny (Air Separator). Utility Model Application No W124984, 31 December 2018. (In Polish).

18. Stanisz, A. Przystęny kurs Statystyki w Oparciu o Program STATISTICA PL na Przykładach z Medycyny. Tom 1. Statystyki Podstawowe (Accessible Course in Statistics Based on the STATISTICA PL Software on Examples from Medicine. Tome 1. Basic Statistics); StatSoft Polska: Kraków, Poland, 2007; pp. 1-532. ISBN 8388724185. (In Polish)

(C) 2019 by the authors. Licensee MDPI, Basel, Switzerland. This article is an open access article distributed under the terms and conditions of the Creative Commons Attribution (CC BY) license (http://creativecommons.org/licenses/by/4.0/). 